\title{
THE NEW EU RULES ON ELECTRONIC INSOLVENCY REGISTERS
}

by

\author{
MICHAEL BOGDAN ${ }^{*}$
}

This paper deals with those provisions of the new EU Regulation No. 2015/848

on Insolvency Proceedings (Recast) that create a system of national insolvency registers andestablish a decentralized system for the interconnection of such registers by means of the European e-Justice Portal.

\section{KEY WORDS}

E-justice, European Union, Insolvency Proceedings, Insolvency Registers

The EU Regulation No. 2015/848 of the European Parliament and of the Council on Insolvency Proceedings (Recast), published in the Official Journal of the European Union on 5 June $2015,{ }^{1}$ is intended to replace, on 26 June 2017, the present Council Regulation No. 1346/2000 on Insolvency Proceedings. ${ }^{2}$ Even though the new Insolvency Regulation (in the following "the Regulation") purports to be a mere recast of its predecessor, it contains a number of new features, one of them being the subject of this paper.

The Regulation, like its predecessor, accepts the fact that the rules of substantive insolvency law, such as rules on security interests and preferential rights, vary widely among the Member States of the European Union, making it impossible to introduce truly European

\footnotetext{
Michael.Bogdan@jur.lu.se, Professor of Law, University of Lund, Sweden.

1 Regulation (EU) No. 2015/848 of the European Parliament and of the Council of 20 May 2015 on insolvency proceedings (recast). Official Journal of the European Union (O.J. 2015 L 141/19) 5 June. Available from: http://eur-lex.europa.eu/legal-content/EN/TXT/PDF/? uri=CELEX:320 15R0848 [Accessed 31 May 2017].

2 Council regulation (EC) No. 1346/2000 of 29 May 2000 on insolvency proceedings. Official Journal of the European Communities (O.J. 2000 L 160/1) 30 June. Available from: http://eur-lex. europa.eu/legal-content/EN/TXT/PDF/?uri=CELEX:32000R1346\&qid=1496217899248 [Accessed 31 May 2017].
} 
insolvency proceedings, treating the whole EU as a single jurisdiction. No attempt is made to create supra-national insolvency proceedings governed by EU law. The system is based on national proceedings, governed by national law, and the national insolvency laws are neither unified nor harmonized, subject to some minor exceptions. The Regulation limits itself in principle to regulating aspects of private international law, such as jurisdiction, applicable law, recognition and enforcement, and crossborder cooperation. Like other instruments enacted within the framework of judicial cooperation in civil matters, the Regulation does not apply in relation to Denmark.

The basic controversy within international insolvency law is the conflict between the territorially limited powers of each individual State on the one hand and on the other hand, the very purpose of insolvency proceedings (in the following in an oversimplified manner referred to as "bankruptcy"), i.e. to achieve control of the totality of the debtor's assets in order to achieve the equal treatment of all creditors. At first glance, it might seem that the principle of universality of the proceedings, meaning that there should always be only one single bankruptcy adjudication comprising all assets regardless of where they are situated, is the optimal solution to this conflict. If applied in its pure form, this principle gives exclusive bankruptcy jurisdiction to the courts of one single country, for instance, the country of the debtor's domicile or seat. The courts in other countries must abstain from initiating rival proceedings, recognize the foreign bankruptcy administrator's right to dispose of the local assets and stop individual creditors who might attempt to attach such assets. All creditors have to lodge their claims in the sole bankruptcy proceedings and satisfy themselves with the dividends they receive in those proceedings. in real life, however, things are not that simple. Reasonable and realistic solutions in this field must be based on compromises between the principle of universality and the opposite principle of territoriality, which, in its pure form, means that a bankruptcy comprises only the assets situated in the country where the bankruptcy was opened and that separate bankruptcy proceedings have to be initiated in each country where the debtor owns assets.

The system created by the EU is consequently also based on a compromise between the two principles. The starting point and the main rule, following from Article 3(1) of the Regulation, is that 
the Regulation applies only where the debtor's "centre of main interests" is situated within the territory of a Member State, and that the courts of that Member State have exclusive jurisdiction to open "main insolvency proceedings" comprising the debtor's assets in the whole EU (whether the proceedings have the ambition to comprise assets outside of the EU is not dealt with by the Regulation and depends thus on the national law of the Member State of the opening of the proceedings). This basically universalist, or at least truly European, approach is partially modified by the same Article 3, which allows each Member State where the debtor owns an establishment to open insolvency proceedings despite the debtor's centre of main interest being in another Member State; the effects of such secondary insolvency proceedings are, however, territorial in the sense that they are restricted to the assets of the debtor situated in the territory of the Member State where they have been opened.

One of the major obstacles standing in the way of the universality or extraterritorial effects of bankruptcies is the risk that persons residing in countries other than the country of the opening of the proceedings do not find out about them, since the usual publicity measures, such as advertising in the official gazette of the country of bankruptcy, have very little effect abroad. This may lead to two types of negative consequences. The first type is that creditors residing in other countries may suffer economic losses due to their failure to participate in the proceedings by lodging their claims or due to lodging their claims too late. The second is that persons abroad who owe debts to the bankrupt, unaware of the opening of the proceedings and of the bankrupt's loss of legal control of his assets, discharge their debts to the bankrupt instead of to the bankruptcy administrator (in the Insolvency Regulation of 2000 ominously called "liquidator", but in the new Regulation given the more appealing title "insolvency practitioner"). As the Regulation grants "main insolvency proceedings" extraterritorial effects within the whole EU, it is compelled to deal with the potential negative consequences of the two kinds just described.

The need to protect persons who, acting in good faith, pay their debts to the bankrupt instead of to the bankruptcy administrator is dealt with by Article 28 of the Regulation, which obliges the insolvency practitioner to request that notice of the judgment opening the proceedings be published in any other Member State where the debtor has an establishment, in accordance with the publication procedures provided 
for there. He can request such publication also in other cases, if he deems it necessary. The law of the Member State of an establishment, or where the debtor owns immovable property, can also require that the decision be published in the land register, company register or any other public register (Article 29). Registration according to Article 28 must not be made a precondition for the recognition of the proceedings opened in another Member State (Recital 75), but it can be decisive for the determination of whether a person, who has paid his debt there to the bankrupt ${ }^{3}$ instead of to the insolvency practitioner, has acted in good faith and is therefore discharged of the debt (Article 31). Payments made before the publication are presumed, in the absence of proof to the contrary, to have been made in good faith, while later payments are presumed to have been made with knowledge about the opening of the proceedings. These provisions are similar but not identical to Articles 21, 22, and 24 of the Regulation of 2000. For example, while Article 21 of the 2000 Regulation provides that the bankruptcy administrator "may" request that notice of the judgment opening the proceedings be published in another Member State, Article 28 of the new Regulation stipulates that such request must ("shall") be made in any Member State where the debtor has an establishment. The abovementioned registers can in most European countries nowadays be accessed online, but this depends on the domestic law of the country of the register concerned.

The described publicity measures do not, however, remove the most difficult problem caused by the fact that the foreign creditors of the bankrupt may not be aware of the proceedings and thus fail to lodge their claims in a timely manner. Such creditors may reside in many countries, and their existence and residence may be unknown to the bankruptcy administrator. Advertising every bankruptcy in all other Member States would be expensive and require much administrative work. The idea of advertising all bankruptcies, or at least all bankruptcies with substantial assets, in a special annex to the Official Journal of the European Communities was discussed several decades ago and quickly discarded due to the large daily volumes it would require. The advent of the new information technologies has radically changed the situation, making it possible to easily access and process large amounts of information

See the ECJ judgment Van Buggenhout v. Banque internationale (2013) Case C-251/12, Court of Justice of the European Union (Third Chamber), 19 September. 
in a digital form. The focus of this paper is, therefore, on a completely new feature in the new Regulation's Articles 24-27, namely the system of interconnected national insolvency registers having no counterpart in the Regulation of 2000. This novelty will be of great practical importance, even though pursuant to Article 24(5) the publication of information in this system of registers will not have any legal effect under the Regulation other than that set out in national law and in Article 55(6), the latter requiring creditors to lodge their claims within the period of time stipulated by the law of the Member State of the opening of the proceedings. In respect of creditors from the other Member States, this period must not be less than thirty days following the publication of the opening in the insolvency register of the Member State of the proceedings.

Article 24(1) of the new Regulation obliges the Member States, by 26 June 2018, to establish and maintain in their territory a national register or several national registers called "insolvency registers", where information concerning insolvency proceedings is to be published as soon as possible after the proceedings have been opened. The registers will be accessible to the general public, so that the information contained therein will be publicly available. Article 24(2) lists the information that must be made public in this manner (the Regulation speaks of "mandatory information"). The list includes, inter alia, the type and date of the opening of the insolvency proceedings, the court and the case number (if any), whether the proceedings are "main insolvency proceedings" or not, the debtor's name, registration number (if any) and address, the name and address of the appointed insolvency practitioner, where and how the decision opening the proceedings can be challenged and, most importantly, the time limit for lodging claims or a reference to the criteria for calculating that time limit. If they wish, Member States are free to include in their registers additional information; they may make access to such additional information conditional, for example, upon the existence of a legitimate interest on the part of the person requesting the information. Such conditions cannot, however, be imposed as far as access to the mandatory information is concerned.

In view of Article 24(3), permitting Member States to include additional information in their insolvency registers, and Article 24(5), permitting Member States to give the publication in their insolvency registers additional legal effects set out in national law, it seems that a Member State 
can use its new insolvency register to replace the traditional publication in the Official Gazette and thus give the register even the effects under Article 31 regarding the discharge of debtors who have paid their debts to the bankrupt instead to the bankruptcy administrator (see supra).

Article 24 does not explicitly require that the national insolvency registers be accessible in an electronic form, but that requirement, which was probably considered so self-evident that it was not worth mentioning, follows from the rules in Article 25 on the interconnection of the national insolvency registers described above.

In accordance with Article 25(1), the Commission will namely establish a system for the interconnection of the national insolvency registers, composed of the national registers themselves and a central public electronic "access point" functioning as entrance to the information contained therein. As this access point will serve the existing European e-Justice Portal, which will provide a search service in all of the EU official languages. Pursuant to Article 25(2)(a), the Commission is required to issue, by 26 June 2019, implementing acts regulating the various technical aspects of the interconnection, such as the technical specifications

"defining the methods of communication and information exchange by electronic means on the basis of the established interface specification of the system of interconnection of insolvency registers,"

the minimum information technology security standards for communication and distribution of information, minimum criteria for the search service provided by the European e-Justice Portal, minimum criteria for the presentation of the results of such searches, and a glossary containing a basic explanation of the national insolvency proceedings of the Member States.

While each Member State will bear the costs of its national insolvency register, the establishment, maintenance and future development of the system of interconnection of insolvency registers will pursuant to Article 26 be financed from the general budget of the EU. The "mandatory information" in the registers will be publicly available free of charge, but the Member States can impose a reasonable charge for access to the voluntary additional information contained therein; this applies even 
if it is accessed through the system of interconnection of insolvency registers via the European e-Justice Portal.

The creation of the system of national insolvency registers and their interconnection at the European level will require a substantial effort and time. Even though the Regulation as such is to apply to insolvency proceedings opened after 26 June 2017, exception is therefore made for the new register system. According to Article 92, the provisions on establishment of national insolvency registers in Article 24(1) will not apply before 26 June 2018, and Article 25 on the interconnection of insolvency registers will not apply before 26 June 2019. This should give the Member States and the Commission sufficient additional time to construct and test the system.

The functioning of interconnected national insolvency registers involves obviously sharing of potentially sensitive personal information concerning debtors who are natural persons (human beings). Therefore, Article 24(4) gives the Member States the right not to include in their national registers information relating to individuals not exercising an independent business or professional activity, or to exclude such information from the European interconnecting registration system. The publication of "mandatory information" in the insolvency register and in the European system can with regard to such persons be replaced by individually informing known "foreign creditors" (meaning creditors having their habitual residence, domicile or registered office in the other Member States), but the proceedings in question shall not affect the claims of such creditors who have not received the information.

Equally important is that all processing by the Member States of personal data within the framework of the Regulation will be in principle subject to EU rules on the protection of personal data, namely Regulation No. 2016/679 of 27 April 2016 on the Protection of Natural Persons with regard to the Processing of Personal Data and on the Free Movement 
of Such Data, ${ }^{4}$ whereas the Commission's European e-Justice Portal must abide by Regulation No. 45/2001 on the Protection of Individuals with regard to the Processing of Personal Data by the Community Institutions and Bodies and on the Free Movement of Such Data. ${ }^{5}$ According to Article 79 of the Insolvency Regulation, each Member State must designate a person or body that will exercise the functions of controller in accordance with the EU personal data protection rules and communicate its name to the Commission, which will publish it on the European e-Justice portal. With regard to that Portal, it is the Commission itself that will assume the responsibilities of controller pursuant to Regulation No. 45/2001. Articles 82 and 83 of the Insolvency Regulation make it clear that the Portal will not store any personal data, which will be kept in the national insolvency registers only and remain accessible via the Portal only for as long as they remain accessible in the national registers pursuant to national law.

\section{LIST OF REFERENCES}

[1] Regulation (EU) No. 2015/848 of the European Parliament and of the Council of 20 May 2015 on insolvency proceedings (recast). Official Journal of the European Union (O.J. 2015 L 141/19) 5 June. Available from: http://eur-lex.europa.eu/legalcontent/EN/TXT/PDF/ uri=CELEX:32 015 R0848 [Accessed 31 May 2017].

4 Regulation (EU) No. 2016/679 of the European Parliament and of the Council of 27 April 2016 on the protection of natural persons with regard to the processing of personal data and on the free movement of such data, and repealing Directive 95/46/EC (General Data Protection Regulation). Official Journal of the European Union (O.J. 2016 L 119/1) 4 May. Available from: http://eur-lex.europa.eu/legal-content/EN/TXT/PDF/?uri=CELEX: 32016R0679 [Accessed 31 May 2017]. At the time of writing, this new Regulation is not yet applicable, but it will become applicable as from 25 May 2018, i.e. simultaneously with the beginning of the use of national insolvency registers and one year before the interconnection of national insolvency registers starts functioning on 26 June 2019. Regulation No 2016/679 will on 25 May 2018 replace the current Directive 95/46 on the Protection of Individuals with regard to the Processing of Personal Data and on the Free Movement of Such Data, O.J. 1995 L 281 p. 31. The new Insolvency Regulation refers in Article 78 and 79 to Directive 95/46, but these references shall be construed as references to Regulation No 2016/679, see Article 94 thereof.

5 Regulation (EC) No. 45/2001 of the European Parliament and of the Council of 18 December 2000 on the protection of individuals with regard to the processing of personal data by the Community institutions and bodies and on the free movement of such data. Official Journal of the European Communities (O.J. 2001 L 8/1) 12 January. Available from: http://eurlex.europa.eu/legal-content/EN/TXT/PDF/?uri=CELEX:32001R0045 [Accessed 31 May 2017]. 